\title{
Effective Learning of Mathematics by Year 7 Students using the Bar Model Method: Case of Brunei Students
}

\author{
Ernie Sofinah Matzin \\ Duli Pengiran Muda Al-Muhtadee Billah College \\ Gadong BE1318, Bandar Seri Begawan, Brunei Darussalam \\ E-mail: ernie.matzin@md.moe.edu.bn \\ Lawrence Mundia (Corresponding author) \\ Sultan Hassanal Bolkiah Institute of Education, Universiti Brunei Darussalam \\ Gadong BE1410, Bandar Seri Begawan, Brunei Darussalam \\ E-mail: lawrence.mundia@ubd.edu.bn
}

\author{
Received: Nov. 13, 2017 Accepted: Dec. 11, 2017 Published: February 1, 2018 \\ doi:10.5296/jse.v8i1.12177 URL: https://doi.org/10.5296/jse.v8i1.12177
}

\begin{abstract}
Mathematics is one of the challenging subjects in the Brunei education system. Achievement rate in this subject is often low especially among males. Both barriers and enablers of success need to be identified early to help fix the problem. The present field survey $(\mathrm{N}=254$ randomly selected Year 7 students, 144 males and 110 females) examined the: (1) attitudes and perceptions of students towards the Bar Model Method (BMM) of teaching and learning mathematics; (2) predictors of achievement in mathematics; and (3) effectiveness of the BMM in teaching and learning mathematics. Both genders and age-groups had positive attitudes and perceptions towards the BMM. In addition, the majority of participants (all genders, age-groups and districts) stated that the BMM was effective and liked the strategy. Furthermore, the participants' Word Problem-Solving Achievement Test (WPSAT) posttest scores did not differ significantly by gender and age-group. However, students in Brunei-Muara and Kuala Belait districts scored significantly higher at the posttest level than those in Tutong. Two implications were drawn from this finding. First, schools in Tutong might not be well-resourced like those in the other two districts. Second, more BMM work with students was required in Tutong to facilitate mastery of the strategy.
\end{abstract}

Keywords: Bar Model Method, attitudes, perceptions, predictors, effectiveness 


\section{Introduction}

The Bar Model Method (BMM) uses bar diagrams to model facts given in a word problem (Walker, 2005; 2006). Walker (2005) stressed and contended that the approach was useful in organizing information. According to Yeap (2010), the BMM helps students solve arithmetic and algebraic word problems. He further said that the procedure was a common problem-solving heuristic used in Singapore schools. The BMM is ideal as a 'linking' method for problem solving in mathematics from one level to the next (Huat \& Huat, 2001). Studies (e.g. Bishop, 1989; Veloo \& Lopez, 1994; Fong, 1997; and Huat \& Huat, 2001) indicate that the model helps students to visualize situations, create concrete pictures from abstract situations, and transform words into recognizable pictures for the mind to analyze. According to Huat and Huat (2001), the introduction of model drawing involves six stages of representation before the box diagrams are used. This method is taught to primary school children in Singapore ( $\mathrm{Ng} \&$ Lee, 2009). The method is embedded into the primary mathematics curriculum. According to Kho $(1987 ; 2009)$ the model can be used as a tool for solving both arithmetic and algebraic word problems involving whole numbers, fractions, ratios and percentages. Once students understood the structure of the problem, they were more likely to be able to solve it (Kho, 1987; 2009). The purpose of this study is therefore to investigate the effectiveness of the BMM strategy in enhancing the mathematics achievement and problem solving skills among the secondary school students in Brunei Darussalam. Specifically, the research sought to understand how primary school children could, through experience, effectively learn mathematics using the BMM to improve performance (Suffolk $\&$ Gurung, 2005). The BMM could help students in understanding and solving different types of mathematical problems (Nayan, 1998; Mohiddin, 2001; Mawang, 2001).

\section{Learning and teaching psychological research on Brunei education system}

This is the first time research was done about the effectiveness of the BMM strategy of teaching and learning mathematics with young students in Brunei. Past research of a psychoeducation nature had addressed a number of problems such as various disabilities (Bradshaw \& Mundia, 2005; Bradshaw \& Mundia, 2006; Tait \& Mundia, 2012a, b; Haq \& Mundia, 2012; Mundia, 2006; Yusuf \& Mundia, 2014; Tait \& Mundia, 2014; Tait, Mundia, \& Fung, 2014; Tait, Mundia, Fung, \& Wong, (2014). Besides disability, previous research also examined the mental health concerns of students in the education system (Mundia 2010a; Mundia, 2010b; Mundia 2012a, b; Mundia, 2013; Mundia, 2015). Most of the teaching and learning research on Brunei has focused on a wide range of school subjects including mathematics and Japanese language (Mundia, 1998; Mundia, 2010c; Mundia, 2010d; Mundia, 2007; Mundia, (2009); Mundia, 2011a; Mundia, 2012c; Keaney \& Mundia, 2014). The training of teachers was also accorded priority by research (e.g. Mundia, 2012d, e; Tait \& Mundia, 2012b; Tait \& Mundia, 2014). Problems associated with conducting research using Brunei student samples were investigated by two studies (see Mundia \& Bakar, 2010; Mundia, 2011b).

\section{Research Questions}

The present study investigated the following seven research questions (RQs): 


\section{Macrothink}

RQ1: Do Year 7 students' attitudes towards the BMM strategy differ significantly by gender?

RQ2: Is there a significant difference in Year 7 students' attitudes to the BMM strategy by age-group?

RQ3: Are Year 7 students in different districts significantly different in attitudes towards the BMM strategy?

RQ4: What variables are significantly related to Year 7 students' achievement in mathematics when using the BMM strategy while learning?

RQ5: Were there significant differences by gender, age and district in Year 7 students' perceptions of how challenging the use of the BMM strategy in solving mathematics word problem was?

RQ6: Did Year 7 students differ significantly by gender, age and district in their opinions about the effectiveness of the BMM strategy in solving mathematics word problems?

RQ7: Do Year 7 students' mathematics WPSAT scores differ significantly by gender, age and district before and after using the BMM strategy?

\section{Method}

The methodology for the present study comprised of the design, participants, instruments, data analysis techniques, and procedures, each of which is briefly explained below.

\section{Design}

We used a mixed methods design incorporating a quantitative field survey and a pretest-posttest experiment. These procedures enabled the researchers to collect the needed data from a big sample timely.

\section{Sample}

Participants of the study consisted of 254 Year 7 students representing both genders and chosen from different schools by the simple random selection procedure. Table 1 profiles selected characteristics of the participants by gender, age-group, and district. Temburong district was excluded since it has only one school. 
Table 1. Demographic information of the Year 7 Students $(\mathrm{N}=254)$

\begin{tabular}{llll}
\hline Variable & Group & Frequency & Percentage \\
\hline \multirow{2}{*}{ Gender } & Male & 144 & 56.7 \\
& Female & 110 & 43.3 \\
Age-group & $11-12$ years & 211 & 83.1 \\
& $13-14$ years & 43 & 16.9 \\
District & & & \\
& Brunei-Muara & 183 & 72.0 \\
& Kuala Belait & 44 & 17.3 \\
& Tutong & 27 & 10.6 \\
\hline
\end{tabular}

\section{Instruments}

The data for the current study were collected by three instruments presented in Table 2 . The positive and negative attitudes questionnaires to BMM were both Likert scales with a 4-point response format (1SD, 2D, 3A, 4SA). The reliability for these two instruments was assessed by alpha method. As its name implies, the Word Problem-Solving Achievement Test (WPSAT) consisted of worded mathematics items that students had to solve manually. The response to each item was coded as: 0 (when wrong) and 1 (if correct). Partially correct responses were not taken into consideration. The WPSAT was administered as both a pretest and posttest to the same group of learners before and after students learnt mathematics using the BMM. We used the Kuder-Richardson 21 (KR21) procedure to determine the reliability of the WPSAT. The theoretical assumption underpinning this internal consistency method requires items to have nearly the same difficulty level (Ary et al., 2002). Failure to meet this assumption or violation of it, will result in the procedure underestimating the reliability of the test and thereby giving a lower-bound value. To avoid this problem, we picked 10 items with p-values or facility indices of about 0.50 from a pool of 17 WPSAT questions that we pretested. All the instruments were reliable as shown in Table 2.

Table 2. Descriptive statistics and reliability of the instruments $(\mathrm{N}=254)$

\begin{tabular}{|c|c|c|c|c|c|}
\hline Scales & Items & Mean & SE Mean & SD & Reliability \\
\hline Positive attitudes to BMM & 17 & 46.350 & 0.526 & 8.394 & $0.891^{\mathrm{a}}$ \\
\hline Negative attitudes to BMM & 5 & 11.300 & 0.151 & 2.412 & $0.719^{\mathrm{a}}$ \\
\hline $\begin{array}{l}\text { Word Problem-Solving Achievement Test } \\
\text { (WPSAT)- Pretest }\end{array}$ & 10 & 1.750 & 0.201 & 3.207 & $0.955^{\mathrm{b}}$ \\
\hline $\begin{array}{l}\text { Word Problem-Solving Achievement Test } \\
\text { (WPSAT)- Posttest }\end{array}$ & 10 & 3.780 & 0.262 & 4.180 & $0.962^{\mathrm{b}}$ \\
\hline
\end{tabular}

${ }^{\mathrm{a} C}$ Cronbach alpha

${ }^{\mathrm{b}}$ Kuder-Richardson 21 (KR21) 
With regard to the validity of the instruments, the two attitude scales (positive and negative attitudes to the BMM) correlated negatively and significantly $[\mathrm{r}(254)=-0.290, \mathrm{p}<.01$, two-tailed]. This significant negative relationship provided quantitative evidence that the two scales had adequate discriminant validity. On the other hand, pretest and posttest scores from the Word Problem-Solving Achievement Test (WPSAT) correlated positively and significantly $\left[\mathrm{r}_{\text {prepost }}(254)=0.713, \mathrm{p}<.01\right.$, two-tailed]. The significant positive relationship demonstrated that the pre-post scores had sufficient convergent validity.

\section{Procedures}

The present study was funded by the Government of Brunei Darussalam in form of a doctoral study grant to the first author at the University of Brunei Darussalam (UBD). In turn, the University of Brunei Darussalam Ethics Committee approved the study on behalf of the government. Furthermore, ethical conditions and rights (e.g. anonymity, confidentiality, privacy, voluntary participation, protection from harm, and informed consent) for participating in the study were first explained verbally in both English and Bahasa Melayu language to individual research participants' parents and school authorities prior to collecting the data from young students. After this, verbal and written informed consent were secured from each research participant's parents in either of the two languages at the time and place of collecting the data. Only students whose parents voluntarily agreed to let their children be involved in the study were recruited to participate. Coercion and deception were not used when recruiting the participants. Furthermore, all the study's research tools were written in simple English language requiring only Grade 7 or Year 7 level of education. To address and reduce any possible linguistic and cultural biases, parallel bilingual items were presented on the instruments in both English and Bahasa Melayu, the main and official language of Brunei spoken by the majority of the people. Above all, data collection occurred in in the participants' school environments to increase the study's ecological validity.

\section{Data analysis}

Data were analyzed using descriptive statistics (frequencies, percentages, mean, and standard deviation) and inferential statistics (Pearson correlations, independent groups t-tests, $\mathrm{X}^{2}$, and hierarchical multiple regression analysis). To determine the importance of our findings, we used two-tailed tests of statistical significance at both $p=0.05$ and $p=0.01$ levels and tests of statistical power such as $\mathrm{R}^{2}$ (for multiple regression analysis, effect sizes (for t-tests and One-Way ANOVA analyses), and phi coefficients (for chi-square analyses). All the statistical analyses were performed on SPSS Version 22.

\section{Results}

The results are presented below according to the research questions probed. Tables were used to summarize the findings.

RQ1: Do Year 7 students'attitudes towards the BMM strategy differ significantly by gender?

No statistically significant differences were obtained by gender. In relative terms however, Table 3 shows that the female students had more positive attitudes than males. 
Table 3. Year 7 students' attitudes towards the BMM strategy by gender $(\mathrm{N}=254)$

\begin{tabular}{|c|c|c|c|c|c|c|c|c|}
\hline \multirow[t]{2}{*}{ Scales } & \multicolumn{2}{|c|}{$\begin{array}{l}\text { Males } \\
(n=145)\end{array}$} & \multicolumn{2}{|c|}{$\begin{array}{l}\text { Females } \\
(n=109)\end{array}$} & \multirow{2}{*}{$\begin{array}{l}\text { ANCOVA } \\
\text { F }\end{array}$} & \multirow{2}{*}{$\begin{array}{l}\mathrm{T} \\
(\mathrm{df}=252)\end{array}$} & \multirow{2}{*}{$\begin{array}{l}\mathrm{P} \\
\text { (two-tailed) }\end{array}$} & \multirow[t]{2}{*}{$\eta$} \\
\hline & Mean & SD & Mean & SD & & & & \\
\hline $\begin{array}{l}\text { Positive } \\
\text { Attitudes }\end{array}$ & 45.74 & 8.498 & 47.16 & 8.183 & 0.091 & -1.331 & 0.184 & 0.084 \\
\hline $\begin{array}{l}\text { Negative } \\
\text { Attitudes }\end{array}$ & 11.34 & 2.343 & 11.25 & 2.502 & 0.212 & 0.295 & 0.768 & 0.019 \\
\hline
\end{tabular}

RQ2: Is there a significant difference in Year 7 students' attitudes to the BMM strategy by age-group?

There were no statistically significant differences by age-groups as shown by evidence in Table 4.

Table 4. Year 7 students' attitudes towards the BMM strategy by age $(\mathrm{N}=254)$

\begin{tabular}{|c|c|c|c|c|c|c|c|c|}
\hline \multirow[t]{2}{*}{ Scales } & \multicolumn{2}{|c|}{$\begin{array}{l}\text { 11-12 Years } \\
(n=211)\end{array}$} & \multicolumn{2}{|c|}{$\begin{array}{l}\text { 13-14 Years } \\
(\mathrm{n}=43)\end{array}$} & \multirow{2}{*}{$\begin{array}{l}\text { ANCOVA } \\
\text { F }\end{array}$} & \multirow{2}{*}{$\begin{array}{l}\mathrm{T} \\
(d f=252)\end{array}$} & \multirow{2}{*}{$\begin{array}{l}\text { P } \\
\text { (two-tailed) }\end{array}$} & \multirow[t]{2}{*}{$\eta$} \\
\hline & Mean & SD & Mean & SD & & & & \\
\hline $\begin{array}{l}\text { Positive } \\
\text { Attitudes }\end{array}$ & 46.64 & 8.075 & 44.91 & 9.705 & 1.519 & 1.241 & 0.216 & 0.078 \\
\hline $\begin{array}{l}\text { Negative } \\
\text { Attitudes }\end{array}$ & 11.24 & 2.373 & 11.58 & 2.584 & 0.280 & -0.843 & 0.400 & 0.053 \\
\hline
\end{tabular}

RQ3: Are Year 7 students in different districts significantly different in attitudes towards the BMM strategy?

As indicated in Table 5, students in Kuala Belait district scored significantly higher on positive attitudes scale towards the BMM than peers in Brunei-Muara and Tutong districts $[\mathrm{F}(\mathrm{df}=2,253)=7.924, \mathrm{p}<.001, \mathrm{y}=0.244]$. This difference was associated with an appreciable effect size.

Table 5. Year 7 students' attitudes towards the BMM Strategy by district $(\mathrm{N}=254)$

\begin{tabular}{|c|c|c|c|c|c|c|}
\hline \multirow[t]{2}{*}{ Scales } & $\begin{array}{l}\text { Brunei-Muara } \\
(\mathrm{n}=183)\end{array}$ & $\begin{array}{l}\text { Kuala } \\
\text { Belait } \\
(n=44)\end{array}$ & $\begin{array}{l}\text { Tutong } \\
(n=27)\end{array}$ & \multirow[t]{2}{*}{$\begin{array}{l}\text { F } \\
(d f=2, \\
253)\end{array}$} & \multirow[t]{2}{*}{$\begin{array}{l}\text { P } \\
\text { (two-tailed) }\end{array}$} & \multirow[t]{2}{*}{$\eta$} \\
\hline & Mean (SD) & $\begin{array}{l}\text { Mean } \\
\text { (SD) }\end{array}$ & $\begin{array}{l}\text { Mean } \\
\text { (SD) }\end{array}$ & & & \\
\hline $\begin{array}{l}\text { Positive } \\
\text { Attitudes }\end{array}$ & $\begin{array}{l}45.59 \\
(8.409)\end{array}$ & $\begin{array}{l}50.73 \\
(7.488)\end{array}$ & $\begin{array}{l}44.37 \\
(7.396)\end{array}$ & 7.924 & $0.000 * * *$ & 0.244 \\
\hline $\begin{array}{l}\text { Negative } \\
\text { Attitudes }\end{array}$ & $\begin{array}{l}11.44 \\
(2.426)\end{array}$ & $\begin{array}{l}10.95 \\
(2.372)\end{array}$ & $\begin{array}{l}10.93 \\
(2.336)\end{array}$ & 1.076 & 0.343 & 0.092 \\
\hline
\end{tabular}

$* * * \mathrm{p}<.001$ (two-tailed)

RQ4: What variables were significantly related to Year 7 students' achievement in 
mathematics when using the BMM strategy while learning?

Hierarchical multiple regression analysis with backward elimination was used to identify predictors of mathematics achievement when students were taught using the BMM strategy. Four independent or predictor variables (negative attitudes, gender, positive attitudes, and age) were entered and regressed on mathematics achievement scores (response or dependent variable) in Model 1. The analysis was completed after three iterations or steps. The first required output are presented in Table 6 . Model 1 was significant and accounted for $80.6 \%$ of the common variance between the independent variables and dependent variable.

Table 6. Prediction of Year 7 students' mathematics achievement using hierarchical regression with backward elimination $(\mathrm{N}=254)$

\begin{tabular}{|c|c|c|c|c|c|c|c|c|c|c|c|}
\hline \multirow[t]{2}{*}{ Model } & \multirow[t]{2}{*}{$d f$} & \multirow[t]{2}{*}{$\mathrm{F}$} & \multirow[t]{2}{*}{$\mathrm{R}$} & \multirow[t]{2}{*}{$\mathrm{R}^{2}$} & \multirow{2}{*}{\multicolumn{2}{|c|}{$\operatorname{Adj} R^{2} S E$}} & \multicolumn{5}{|c|}{ Change Statistics } \\
\hline & & & & & & & $\Delta \mathrm{R}^{2}$ & $\Delta \mathrm{F}$ & $d f 1$ & $d f 2$ & Sig. $\Delta \mathrm{F}$ \\
\hline 1 & 4,254 & $259.327 * * *$ & 0.898 & 0.806 & 0.803 & 1.259 & 0.806 & 259.327 & 4 & 250 & $0.000 * * *$ \\
\hline 2 & 3,254 & 346.682 & 0.898 & 0.806 & 0.803 & 1.257 & 0.000 & 0.273 & 1 & 250 & 0.602 \\
\hline 3 & 2,254 & 519.480 & 0.897 & 0.805 & 0.803 & 1.257 & -0.001 & 1.017 & 1 & 251 & 0.314 \\
\hline
\end{tabular}

After removing and adjusting for gender and negative attitudes, the two good predictors of mathematics achievement were age and positive attitudes. Of these, the best predictor was positive attitudes as indicated in Table 7.

Table 7. Predictors of Year 7 students' mathematics achievement using hierarchical regression with backward elimination $(\mathrm{N}=254)$

\begin{tabular}{|c|c|c|c|c|c|c|}
\hline \multirow[t]{2}{*}{ Model } & \multirow[t]{2}{*}{ Variables } & \multicolumn{2}{|c|}{$\begin{array}{l}\text { Unstandardized } \\
\text { Coefficients }\end{array}$} & \multirow{2}{*}{$\begin{array}{l}\text { Standardized } \\
\text { Coefficients } \\
\text { Beta } \\
\end{array}$} & \multirow[t]{2}{*}{$\mathrm{t}$} & \multirow[t]{2}{*}{ Sig. } \\
\hline & & $\mathrm{B}$ & Std. Error & & & \\
\hline \multirow{4}{*}{1} & Gender & 0.170 & 0.155 & 0.091 & 1.097 & 0.274 \\
\hline & Age & -0.255 & 0.174 & -0.198 & -1.467 & 0.144 \\
\hline & Positive Attitudes & 0.064 & 0.007 & 1.059 & 8.632 & $0.000 * * *$ \\
\hline & Negative Attitudes & $\mathrm{s}-0.015$ & 0.028 & -0.060 & -0.523 & 0.602 \\
\hline \multirow{3}{*}{2} & Gender & 0.152 & 0.151 & 0.081 & 1.008 & 0.314 \\
\hline & Age & -0.305 & 0.145 & -0.237 & -2.101 & $0.037 *$ \\
\hline & Positive Attitudes & 0.063 & 0.007 & 1.049 & 8.676 & $0.000 * * *$ \\
\hline \multirow{2}{*}{3} & Age & -0.272 & 0.141 & -0.211 & -1.922 & $0.054 *$ \\
\hline & Positive Attitudes & 0.066 & 0.007 & 1.100 & 10.011 & $0.000 * * *$ \\
\hline
\end{tabular}

$* \mathrm{p}<.05$ (two-tailed)

$* * * \mathrm{p}<.001$ (two-tailed)

RQ5: Were there significant differences by gender, age and district in Year 7 students' perceptions of how challenging the use of the BMM strategy in solving mathematics word problem was? 
No significant differences were obtained by gender. According to Tables 8, the BMM strategy was neither easy nor difficult to use.

Table 8 . Year 7 students' perceptions of the use of BMM strategy by gender $(\mathrm{N}=254)$

\begin{tabular}{|c|c|c|c|c|c|c|c|}
\hline Statement & $\begin{array}{l}\text { Easy } \\
\mathrm{F} \\
(\mathrm{M}) \dagger\end{array}$ & $\begin{array}{l}\text { Neutral } \\
\text { F (M) }\end{array}$ & $\begin{array}{l}\text { Difficult } \\
\text { F (M) }\end{array}$ & $\chi^{2}$ & $\mathrm{df}$ & Phi & $\mathrm{P}$ \\
\hline $\begin{array}{l}\text { How easy/difficult was it to use the } \\
\text { BMM strategy to solve } \\
\text { mathematics word problem? }\end{array}$ & $\begin{array}{l}45 \\
(55)\end{array}$ & $\begin{array}{l}45 \\
(56)\end{array}$ & $\begin{array}{l}19 \\
(34)\end{array}$ & 1.368 & 2 & 0.073 & 0.504 \\
\hline
\end{tabular}

$\dagger \mathrm{F}=$ Females; $\mathrm{M}=$ Males

However, there were significant differences by age. Table 9 shows that most of the younger students aged 12 years and below either found the BMM to be easy or were neutral with no opinion on this matter $\left[\chi^{2}(\mathrm{df}=2)=6.282, Q=0.157, \mathrm{p}<.05\right]$.

Table 9. Year 7 students' Perceptions of the use of BMM strategy by Age $(\mathrm{N}=254)$

\begin{tabular}{lllllllll}
\hline Statement & $\begin{array}{l}\text { Easy } \\
\mathrm{A}(\mathrm{B}) \dagger\end{array}$ & $\begin{array}{l}\text { Neutral } \\
\mathrm{A}(\mathrm{B})\end{array}$ & $\begin{array}{l}\text { Difficult } \\
\mathrm{A}(\mathrm{B})\end{array}$ & $\chi^{2}$ & df & Phi & P \\
\hline $\begin{array}{l}\text { How easy/difficult was it to use } \\
\text { the BMM strategy to solve }\end{array}$ & $\begin{array}{l}87 \\
(13)\end{array}$ & $\begin{array}{l}86 \\
(15)\end{array}$ & $\begin{array}{l}38 \\
(15)\end{array}$ & 6.282 & 2 & 0.157 & 0.043 \\
mathematics word problem? & & & & & & \\
\hline
\end{tabular}

$\dagger \mathrm{A}=12$ years old and below; $\mathrm{B}=13$ years old and above

According to Table 10, no significant differences were obtained by districts as indicated by the chi-square and phi coefficients.

Table 10. Year 7 students' perceptions on use of the BMM strategy by district $(\mathrm{N}=254)$

\begin{tabular}{|c|c|c|c|c|c|c|c|}
\hline Statement & $\begin{array}{l}\text { Easy } \\
1 \quad(2) \\
3 \dagger\end{array}$ & $\begin{array}{l}\text { Neutral } \\
1 \text { (2) } 3\end{array}$ & $\begin{array}{l}\text { Difficult } \\
1 \text { (2) } 3\end{array}$ & $\chi^{2}$ & $\mathrm{df}$ & Phi & $\mathrm{P}$ \\
\hline $\begin{array}{l}\text { How easy/difficult was it to use } \\
\text { the BMM strategy to solve } \\
\text { mathematics word problem? }\end{array}$ & $\begin{array}{l}75 \\
(17) \\
8\end{array}$ & $\begin{array}{l}70 \\
(21) \\
10\end{array}$ & $\begin{array}{l}38 \\
(6) \\
9\end{array}$ & 4.749 & 4 & 0.137 & 0.314 \\
\hline
\end{tabular}

$\dagger 1=$ Brunei-Muara; (2) = Tutong; 3 = Kuala Belait

RQ6: Did Year 7 students differ significantly by gender, age and district in their opinions about the effectiveness of the BMM strategy in solving mathematics word problems?

Tables 11, shows that Year 7 students did not differ significantly by gender in their opinions about the effectiveness of the BMM strategy in solving mathematics word problems. 
Table 11. Year 7 students' opinions on the effectiveness of the BMM strategy by gender $(\mathrm{N}=254)$

\begin{tabular}{llllllll}
\hline Statement & $\begin{array}{l}\text { Ineffective } \\
\mathrm{F}(\mathrm{M}) \dagger\end{array}$ & $\begin{array}{l}\text { Neutral } \\
\mathrm{F}(\mathrm{M})\end{array}$ & $\begin{array}{l}\text { Effective } \\
\mathrm{F}(\mathrm{M})\end{array}$ & $\chi^{2}$ & df & Phi & P \\
\hline $\begin{array}{l}\text { How effective do you think } \\
\text { the BMM strategy is for }\end{array}$ & 15 & 47 & 47 & & & & \\
$\begin{array}{l}\text { solving mathematics word } \\
\text { problem? }\end{array}$ & $(22)$ & $(58)$ & $(65)$ & 0.273 & 2 & 0.033 & 0.873 \\
\hline $\mathrm{F}=$ Females; $\mathrm{M}=$ Males & & & & & & & \\
\hline
\end{tabular}

With regards to the students' opinions in terms of their age, Table 12 shows no significant difference.

Table 12. Year 7 students' opinions on the effectiveness of the BMM strategy by age $(\mathrm{N}=254)$

\begin{tabular}{|c|c|c|c|c|c|c|c|}
\hline Statement & $\begin{array}{l}\text { Ineffective } \\
\mathrm{A}(\mathrm{B}) \dagger\end{array}$ & $\begin{array}{l}\text { Neutral } \\
\text { A (B) }\end{array}$ & $\begin{array}{l}\text { Effective } \\
\mathrm{A}(\mathrm{B})\end{array}$ & $\chi^{2}$ & $\mathrm{df}$ & Phi & $\mathrm{P}$ \\
\hline $\begin{array}{l}\text { How effective do you think } \\
\text { the BMM strategy is for } \\
\text { solving mathematics word } \\
\text { problem? }\end{array}$ & $\begin{array}{l}33 \\
(4)\end{array}$ & $\begin{array}{l}91 \\
(14)\end{array}$ & $\begin{array}{l}87 \\
(25)\end{array}$ & 4.266 & 2 & 0.130 & 0.118 \\
\hline
\end{tabular}

In addition, Year 7 students did not also differ significantly by district in their opinions about the effectiveness of the BMM strategy in solving mathematics word problems (see Table 13).

Table 13. Year 7 students' opinions on the effectiveness of the BMM strategy by district $(\mathrm{N}=254)$

\begin{tabular}{|c|c|c|c|c|c|c|c|}
\hline Statement & $\begin{array}{l}\text { Ineffective } \\
1(2) 3 \dagger\end{array}$ & $\begin{array}{l}\text { Neutral } \\
1(2) 3 \\
\end{array}$ & $\begin{array}{l}\text { Effective } \\
1(2) 3\end{array}$ & $\chi^{2}$ & $d f$ & Phi & $\mathrm{P}$ \\
\hline $\begin{array}{l}\text { How effective do you think } \\
\text { the BMM strategy is for } \\
\text { solving mathematics word } \\
\text { problem? }\end{array}$ & $\begin{array}{l}26 \\
(3) \\
8\end{array}$ & $\begin{array}{l}76 \\
(19) \\
10\end{array}$ & $\begin{array}{l}81 \\
(22) \\
9\end{array}$ & 7.252 & 4 & 0.169 & 0.123 \\
\hline
\end{tabular}

\section{Comparison of the students' Word Problem-Solving Achievement Test (WPSAT) pre-post scores when using the BMM}

RQ7: Do Year 7 students' mathematics WPSAT scores differ significantly by gender, age and district before and after using the BMM strategy?

Based on the findings presented in Tables 14, Year 7 students' mathematics WPSAT scores did not differ significantly by gender before and after using the BMM strategy. 
Table 14. Independent-sample t-test comparison of the WPSAT scores by gender $(\mathrm{N}=254)$

\begin{tabular}{lllllllll}
\hline Assessments & $\begin{array}{l}\text { Males } \\
(\mathrm{n}=144)\end{array}$ & \multicolumn{2}{l}{$\begin{array}{l}\text { Females } \\
(\mathrm{n}=110)\end{array}$} & ANCOVA & $\mathrm{T}$ & $\mathrm{P}$ & $\mathrm{ES}$ \\
& Mean & SD & Mean & SD & F & $(\mathrm{df}=252)$ & (two-tailed) & \\
\hline Pretest scores & 1.660 & 3.261 & 1.870 & 3.145 & 0.369 & -0.524 & 0.601 & 0.033 \\
Posttest scores & 3.570 & 4.240 & 4.050 & 4.102 & 0.663 & -0.916 & 0.360 & 0.058 \\
\hline
\end{tabular}

Tables 15 also shows that Year 7 students' WPSAT mathematics scores did not differ significantly by age before and after using the BMM strategy.

Table 15. Independent-sample t-test comparison of the WPSAT scores by age $(\mathrm{N}=254)$

\begin{tabular}{lllllllll}
\hline Assessments & \multicolumn{2}{l}{$\begin{array}{l}\text { 11-12 Years } \\
(\mathrm{n}=211)\end{array}$} & $\begin{array}{l}\text { 13-14 Years } \\
(\mathrm{n}=43)\end{array}$ & ANCOVA & \multicolumn{2}{l}{ T } & P & ES \\
& Mean & SD & Mean & SD & F & $(\mathrm{df}=252)$ & (two-tailed) & \\
\hline Pretest scores & 1.770 & 3.266 & 1.670 & 2.934 & 0.127 & 0.174 & 0.862 & 0.011 \\
Posttest scores & 3.940 & 4.271 & 2.980 & 3.635 & 4.193 & 1.384 & 0.167 & 0.087 \\
\hline
\end{tabular}

However, Year 7 students' WPSAT mathematics scores differed significantly by district before and after using the BMM strategy as indicated in Table 16. At the pretest level, students in Muara-Brunei district scored significantly higher than peers in Kuala Belait and Tutong districts $[F(d f=2,253)=3.107, p<.05, y=0.155]$. For the posttest phase, students in both Kuala Belait and Brunei-Muara districts scored significantly much higher than their counterparts in Tutong district $[\mathrm{F}(\mathrm{df}=2,253)=6.067, \mathrm{p}<.01, \mathrm{y}=0.215]$.

Table 16. One-Way ANOVA comparison of the WPSAT scores by district $(\mathrm{N}=254)$

\begin{tabular}{|c|c|c|c|c|c|c|}
\hline \multirow[t]{2}{*}{ Assessments } & $\begin{array}{l}\text { Brunei-Muara } \\
(\mathrm{n}=183)\end{array}$ & $\begin{array}{l}\text { Kuala Belait } \\
(\mathrm{n}=44)\end{array}$ & $\begin{array}{l}\text { Tutong } \\
(n=27)\end{array}$ & \multirow[t]{2}{*}{$\begin{array}{l}\mathrm{F} \\
(\mathrm{df}=2,253)\end{array}$} & \multirow[t]{2}{*}{$\begin{array}{l}\mathrm{P} \\
\text { (two-tailed) }\end{array}$} & \multirow[t]{2}{*}{$\eta$} \\
\hline & $\begin{array}{l}\text { Mean } \\
(\mathrm{SD})\end{array}$ & $\begin{array}{l}\text { Mean } \\
(\mathrm{SD})\end{array}$ & $\begin{array}{l}\text { Mean } \\
(\mathrm{SD})\end{array}$ & & & \\
\hline Pretest scores & $\begin{array}{l}2.02 \\
(3.220)\end{array}$ & $\begin{array}{l}1.45 \\
(3.763)\end{array}$ & $\begin{array}{l}0.44 \\
(1.281)\end{array}$ & 3.107 & $0.046^{*}$ & 0.155 \\
\hline Posttest scores & $\begin{array}{l}4.07 \\
(4.214)\end{array}$ & $\begin{array}{l}4.18 \\
(4.597)\end{array}$ & $\begin{array}{l}1.19 \\
(1.711)\end{array}$ & 6.067 & $0.003 * *$ & 0.215 \\
\hline
\end{tabular}

$* \mathrm{p}<0.05$ (two-tailed)

$* * \mathrm{p}<0.01$ (two-tailed)

\section{Discussion}

Both genders and age-groups scored high on positive attitudes toward the BMM strategy in this study. In addition, both genders and age-groups also scored low on negative attitudes toward the BMM. Taken together, these two findings suggested that the majority of the study participants liked the BMM method of teaching and learning mathematics. The BMM appeals to students because it allows them to visualize the problem and think about it concretely before solving it (see Bishop, 1989; Veloo \& Lopez, 1994; Fong, 1997; and Huat \& Huat, 
2001).

All the participants in the three districts scored low on negative attitudes toward the BMM technique but high on positive attitudes. However, students in Kuala Belait had significantly higher positive attitudes toward the BMM than those in Brunei-Muara and Tutong. In general, these findings concur with the attitudinal outcomes discussed above in terms of gender and age-groups but also imply that more BMM work needs to be done with students in Brunei-Muara and Tutong districts. Often it takes a bit of time for students and teachers to get used to the BMM approach for teaching and learning mathematics (Walker, 2005; 2006). Once students and teachers get used to it, the procedure yield good achievement results as in Singapore where it has been in operation for many years (Yeap, 2010).

The strongest and best predictor of mathematics achievement in this study was positive attitudes towards the BMM procedures. Age (a categorical variable) predicted achievement negatively with younger students who learn better with concrete materials and reasoning liking the BMM more than their older peers. The BMM is one several factors that researchers and teachers could help students in understanding and solving different types of mathematical problems (Nayan, 1998; Mohiddin, 2001; Mawang, 2001).

Participants of both genders and age-groups residing in all the three districts held favorable perceptions of the BMM strategy. However, younger students (who prefer learning using concrete materials) had more favorable perceptions compared to their older counterparts. This finding is in agreement with previous research which says the BMM helps students to visualize situations, create concrete pictures from abstract situations, and transform words into recognizable pictures prior to solving the problem (e.g. Bishop, 1989; Veloo \& Lopez, 1994; Fong, 1997; and Huat \& Huat, 2001). With regard to the effectiveness of the BMM strategy, the majority of participants (all genders, age-groups, and districts) thought that it was effective. The success of many primary and secondary school students in mathematics in Singapore has been largely credited to the use of the BMM approach of teaching and learning (Ng \& Lee, 2009; Yeap, 2010).

Evidence from the current study's pre-post experiment showed no significant differences on posttest scores by gender and age on the Word Problem Solving Achievement Test (WPSAT) of mathematics. The elimination of major differences on performance associated with these demographic variables may be attributed to the effectiveness of the BMM strategy for teaching and learning mathematics for young students. Once students understood the structure of the problem through visual or pictorial representation of the data, they were more likely to be able to solve the problem concretely (Kho, 1987; 2009). However, students in Brunei-Muara and Kuala Belait districts scored significantly higher at the posttest level than those in Tutong. This difference might be due to two factors. First, there more students in Brunei-Muara and Kuala Belait districts than in Tutong. Second, the finding calls for more BMM work to be done with mathematics struggling students in Tutong.

\section{Conclusion}

There is ample evidence from the present study indicating that the BMM would be helpful in 


\section{Macrothink

improving mathematics achievement in Brunei Year 7 students. The BMM should therefore be included in teacher education curriculum for both pre-service and in-service training programs. In this way, teachers would be skilled to use the method efficiently during mathematics instruction.

\section{Limitations}

The present study had two main limitations. First, we did not include an interview component with probes to explore further the participants' responses from the quantitative surveys. Second, the sample size was only moderate. Despite these shortcomings, the current study's findings have practical significance that may be relevant to policy-makers and researchers in Brunei and elsewhere.

\section{Declarations}

\section{Abbreviations}

UBD: University of Brunei Darussalam; SPSS: Statistical Package for Social Sciences

\section{Funding}

The study was supported by the Ministry of Education, Government of Brunei Darussalam through a grant to the first author

\section{Competing interests}

The authors declare that they did not have any conflict of interests

\section{Ethics approval and consent to participate}

Permission to conduct the study was obtained from the University of Brunei Darussalam Ethics Committee

\section{Consent for publication and permissions to reproduce material}

Not applicable. The authors declare that they did not use any materials that needed permission from the copyright owners

\section{Authors' contributions}

The authors contributed equally to the article

\section{Acknowledgements}

Not applicable

\section{Requests for data}

The data cannot be released without permission from the participants. Contact the corresponding author on reasonable requests for access to the data

\section{References}

Ary, D., Jacobs, L. C., \& Razavieh, A. (2002). Introduction to research in education (6 ${ }^{\text {th }}$ ed.). 
Belmont, CA: Wadsworth.

Bishop, A. (1989). Review of research in visualization in mathematics education. Focus on Learning Problems in Mathematics, 11(1), 7-16.

Bradshaw, L., \& Mundia, L. (2005). Understanding preservice teachers' construct of disability: a metacognitive process. Disability and Society, 20(5), 563-574. https://doi.org/10.1080/09687590500156329

Bradshaw, L., \& Mundia, L. (2006). Attitudes to and concerns about inclusive education: Bruneian inservice and preservice teachers. International Journal of Special Education, 21(1), $35-41$.

Fong, H. K. (1997). One mathematical problem but FIVE possible solutions. Singapore: In Science and Mathematics education (pp. 14-16). Bandar Seri Begawan: University of Brunei Darussalam.

Haq, F. S., \& Mundia, L. (2012). Comparison of Brunei pre-service student teachers' attitudes to inclusive education and specific disabilities: Implications for teacher education. Journal of Educational Research, 105 (5), 366-374. Routledge/Francis \& Taylor. https://doi.org/10.1080/00220671.2011.627399

Huat, J. N. C., \& Huat, L.K. (2001). Teacher works: Mathematics teachers in primary schools. Singapore Times Media Private Limited.

Keaney, M., \& Mundia, L (2014). Foreign language learners' motivation and its effects on their achievement: Implications for effective teaching of students studying Japanese at Universiti Brunei Darussalam. International Education Studies, 7(9), 122.

Kho, T. H. (1987). Mathematical models for solving arithmetic problems. Proceedings of the Fourth Southeast Asian Conference on Mathematical Education (ICMI-SEAMS), Mathematical Education in the 1990's, pp. 345-351. Singapore: Institute of Education.

Kho, T. H., Yeo, S. M., \& Lim, J. (2009). The Singapore Bar Model Method for Learning Mathematics. Singapore: EPB Pan Pacific.

Mawang, R. (2001). An investigation of errors made by Primary 6 pupils in word problems involving fractions. Unpublished M.Ed. dissertation, University Brunei Darussalam.

Mohiddin, R. (2001). The difficulties faced by students of Brunei Darussalam in transforming short mathematical word statements into algebraic form. Unpublished M.Ed. dissertation, University Brunei Darussalam.

Mundia, L (2015). The Relationship between Personality and Emotional Intelligence: An Exploratory Case of Brunei Student Teachers. Mediterranean Journal of Social Sciences, 6(6 S1), 133. https://doi.org/10.5901/mjss.2015.v6n6s1p133

Mundia, L. (2006). Aggressive behavior among Swazi upper primary and junior secondary school students: implications for ongoing educational reforms concerning inclusive education. International Journal of Special Education, 21(3), 58-67. 
Mundia, L. (2007). Early childhood education in Swaziland and Brunei Darussalam: goals, achievements and challenges. Early Child Development and Care, 177(2), 151-158. https://doi.org/10.1080/03004430500375885

Mundia, L. (2009). Implementation of inclusive education in Brunei Darussalam: Review of possible implications on school counsellors. Electronic Journal for Inclusive Education, 2(4). Available online: http://www.cehs.wright.edu/ prenick/Spring_Summer09_Edition/spr_sum09.html

Mundia, L. (2010a). Prevalence of depression, anxiety and stress in Brunei student teachers. Internet Journal of Mental Health, 6(2).

Mundia, L. (2010b). Brunei trainee teachers' coping strategies for stressful situations. International Journal of Psychological Studies, 2(1), 79-88. https://doi.org/10.5539/ijps.v2n1p79

Mundia, L. (2010c). Problems in learning mathematics: Comparison of Brunei junior high school students in classes with and without repeaters. Journal of Mathematics Research, 2(3), 150-160. https://doi.org/10.5539/jmr.v2n3p150

Mundia, L. (2010d). Implementation of SPN21 curriculum in Brunei Darussalam: A review of selected implications on school assessment reforms. International Education Studies, 3(2), 119-129. https://doi.org/10.5539/ies.v3n2p119

Mundia, L. (2011a). Effects of psychological distress on academic achievement in Brunei student teachers: Identification challenges and counseling implications. Higher Education Studies, 1(1), 51-63. https://doi.org/10.5539/hes.v1n1p51

Mundia, L. (2011b). Social desirability, non-response bias and reliability in a long self-report measure: Illustrations from the MMPI-2 administered to Brunei student teachers. Educational Psychology: An International Journal of Experimental Educational Psychology, 31(2), 207-224. https://doi.org/10.1080/01443410.2010.545049

Mundia, L. (2012a). The mental health profiles of student teachers: Relevance to teacher education and in identifying potential future teacher problems. The Internet Journal of World Health and Societal Politics, 7(2). https://doi.org/10.5580/2c75

Mundia, L. (2012b). The role of cognitive behavior therapy in fighting non-adherence to medical advice maintained by fear of drug side-effects in a man with cholesterol, obesity and hypertension problems. The Internet Journal of Health, 13(1). https://doi.org/10.5580/2c41

Mundia, L. (2012c). The Assessment of Mathematics Learning Difficulties in a Primary Grade 4 Child with High Support Needs: Mixed Methods Approach. International Electronic Journal of Elementary Education, 4(2), 347-366.

Mundia, L. (2012d). Assessment of GenNEXT learning outcomes at the University of Brunei Darussalam: A qualitative review of selected opportunities, benefits and challenges in human resource development. Journal of International Education and Leadership, 2(3), Fall 2012. 
Mundia, L. (2012e). Policy changes in Brunei teacher education: Implications for the selection of trainee teachers. The Education Forum, 76(3), 326-342. https://doi.org/10.1080/00131725.2012.682489

Mundia, L. (2013). Relationship between Mental Health and Teaching: Evidence from Brunei Trainee Teachers. International Journal of Mental Health, 42(2/3), 73-98. https://doi.org/10.2753/IMH0020-7411420205

Mundia, L., Bakar, HAZBA. (2010). The suitability of the EPQ-R short scale for counseling Brunei student teachers when administered in English and Malay languages. Compare, 40(5), 641-658. https://doi.org/10.1080/03057920903478654

Nayan, S. (1998). Problem solving errors by primary six children in specialist teachers' project schools. Unpublished M.Ed. dissertation, Sultan Hassanal Bolkiah Institute of Education, University of Brunei Darussalam.

Ng, S. F., \& Lee, K. (2009). The Model Method: Singapore children's tool for representing and solving algebraic word problems. Journal for Research in Mathematics Education, 40(3), 282-313.

Suffolk, J., \& Gurung, C. (2005). Performance in solving word problems by Nepalese and Bruneian children. In H.S. Dhindsa, I.J.Kyeleve, O. Chukwu \& J.S.H.Q. Perera (Eds.). Future directions in science, mathematics and technical education (pp. 177-186). Bandar Seri Begawan: University of Brunei Darussalam.

Tait, K, Mundia, L, Fung, F, \& Wong, C. (2014). The impact of traditional Chinese beliefs, stigma and local school service provision on the coping strategies of parents of children with Autism Spectrum Disorders in Hong Kong. Journal of the International Society for Teacher Education, 18(1), 16-25.

Tait, K., \& Mundia, L (2014). A Comparison of Brunei and Hong Kong - SAR Student Teachers' Self-efficacy in Implementing Inclusive Education Practices: Implications for Teacher Education. Asian Social Science, 10(1), 51-60. https://doi.org/10.5539/ass.v10n1p51

Tait, K., \& Mundia, L. (2012a). Preparing teachers to meet the challenges of inclusive education in Negara Brunei Darussalam. In C. I. Forlin (Ed.), Future directions for inclusive teacher education: An international perspective (pp. 60-69). Hong Kong: Routledge/Francis \& Taylor. https://doi.org/10.4324/9780203113585

Tait, K., \& Mundia, L. (2012b). The impact of a child with autism on the Bruneian family system. International Journal of Special Education, 27(3), 1-14.

Tait, K., Mundia, L., \& Fung, F. (2014). Raising Young Children with Autism Spectrum Disorders in Hong Kong: The Impact of Cultural Values and Stigma on Chinese Parents' Coping strategies. International Journal of Advances in Social Science and Humanities, 2(1), 07-157.

Veloo, P. K., \& Lopez-Real, F. (1994). Drawing diagram and solving word problems: A study of a sample of Bruneian primary and secondary school children in mathematics education: 


\section{Macrothink}

Constraints on constructions, Proceedings of the Seventeenth Annual Conference of the Mathematical Education Research Group of Australasia, 2 (pp.667-674). Lismore: Mathematics Education Research Group of Australasia.

Walker, K. (2005). Problem solving and investigational activities in your classroom. Unpublished report. Educational Technology: Sultan Hassanal Bolkiah Institute of Education, University of Brunei Darussalam.

Walker, K. (2006). Methods of Teaching and Learning Mathematics. Solving mathematical word problems using box diagrams. Unpublished report. Educational Technology: Sultan Hassanal Bolkiah Institute of Education, University of Brunei Darussalam.

Yeap, B. H. (2011). Teaching to Mastery-Bar Modeling A Problem-solving Tool. Bar Modeling: A problem-solving Tool from Research to Practice An effective Singapore Math Strategy. Singapore: Marshall Cavendish Education.

Yusuf, N. M., \& Mundia, L. (2014). The status of counseling in Brunei prisons: Qualitative exploratory case study. Journal of Sociological Research, 5(1), 24-39. 